\title{
Experiential Marketing On Brand Advocacy: A Mixed-Method Approach On Global Apple Product Users
}

Ricardo Machado, University of South Africa (UNISA), South Africa Michael C. Cant, University of South Africa (UNISA), South Africa Helen Seaborne, Canada

\begin{abstract}
Traditionally, marketing was about delivering the right product to the consumer at the right place and set at the right price. In recent years, experiential marketing has increased in popularity among companies that aim at delivering holistic experiences to be enjoyed by their consumers. With the technology explosion and the level of development the past number of years, marketers have become more and more focussed on different ways and methods to reach consumers. The use of experiential marketing as a means of getting consumer buy-in and attention is gaining in momentum - with Apple leading the way.

This study made use of a mixed-method approach to determine the relationship between experiential marketing and brand advocacy through brand loyalty. Qualitative research was utilised to deduce themes for brand advocacy for Apple, which was incorporated into the quantitative research in the form of a web-based questionnaire completed by consumers of Apple products. Apple consumers found the experiential marketing efforts by Apple to have an influence on their feeling of loyalty toward the brand. As that feeling of loyalty increased, these consumers displayed a high tendency toward becoming brand advocates for Apple.
\end{abstract}

Keywords: Apple; Experimental Marketing; Consumer Experience; Brand Advocates

\section{INTRODUCTION}

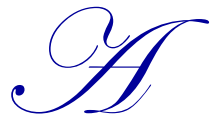

$\mathrm{s}$ the competitive environment increases, marketers are considering new and effective ways to engage consumers so that they will purchase more than before (Little \& King, 2008). Many companies, like Apple, choose to make use of experiential marketing to connect with their consumers by creating products, services, and environments based on a holistic consideration of the consumer's experiences (Diller, Shedroff, \& Rhea, 2005, p. 11). It is about taking the essence of a product and amplifying it into a set of tangible, physical, and interactive experiences that reinforce the offer (Atwal \& Williams, 2009, p. 341) and evoke an emotional response by the consumer with the object of the experience (Chen, Ching, Luo, \& Lui, 2008).

Some of these experiences are so inherently positive that some consumers are taking it upon themselves to become the unpaid sales force behind their beloved brands. Apple has been reaping the benefits of such consumers referred to as brand evangelists - who openly share their experiences and excitement around each Apple encounter.

This study focusses on the actions taken by Apple to market its brand and called on the mixed-method approach to determine whether their experiential marketing efforts had any effect on turning their loyal consumers into brand advocates.

\section{DISCUSSION}

A more traditional view of marketing defines the term as the fulfilling of consumer needs at the expense of competitors, in such a way that the organisation's goals are met (Fahy \& Jobber, 2012, p. 5). Companies would 
make use of superior functional characteristics in the products' design and communication to appeal to the rational consumer. The premise (Schmitt, 2006) behind traditional marketing is that consumers are rational in their approach to satisfy their needs and that the focus will be on product features, and that they will compare the product features and the expected or implied benefits among different products.

On the other hand, the experiential view of marketing sees consumers holistically as rational, as well as emotional, beings (Grundey, 2008, p. 146). Consumers today (Schmitt, 2010) take specific aspects, such as the promised benefits of the product, the appearance, and features, such as quality, usage, and so forth, as a given, and marketers have had to evolve to develop strategies based on an understanding of the consumers' experiences. This is where the goal of experiential marketing lies; namely, to show that the marketer understands the consumers' needs and expectations and, in the process, to deliver this "experience" to him or her.

In order for the marketer to be able to create the experience for the consumer, there has to be some sort of brand identity which, by implication, means that the product must have a well-known brand associated with it. By allowing the consumer to experience the brand, the company is in a position to charge a premium price for the product and, consequently, to potentially increase revenues. This comes about because the consumer sees the experience as unique and is paying not only for the product, but also for the experience. Consumers see value in the experience and reward it with the price they are prepared to pay for it, and therefore it is the responsibility of marketers to create memorable experiences for consumers - experiences that are entertaining to the consumer (Srinivasan \& Srivastava, 2010).

In their daily activities, consumers are exposed to a myriad of marketing stimuli, including various colours, shapes, and sizes, brands and logos, advertising slogans, and product designs. These all form part of the brand's design and identity that marketers want to portray to consumers. These stimuli constitute the major source of subjective, internal consumer responses, which is referred to as "brand experience" (Brakus, Schmitt, \& Zarantonello, 2009, p. 53). How consumers feel about the brand is completely shaped by the interactions they have with the company and its products (Joseph, 2010, p. 15). The evaluation of the experience is a reflection of how the consumer compares the stimuli he or she receives in the formats the marketer offers it and how this experience compares with the expectations the consumer had (Gentile, Spiller, \& Noci, 2007, p. 397).

The goal of branding an experience is to consistently reflect the company's value proposition in its expression in every connection with a consumer (Diller et al., 2005, p. 19). The experience effect connects the expressions of the brand together across all the elements of the marketing plan over periods of time (Joseph, 2010, p. 17).

All experiences are, however, not the same. In some instances, the experience would be more intense and deep, while in other instances, the experience may be planned to be rather more basic or elementary for the consumer (Joseph, 2010, p. 19). Ultimately, the main aim of the experience is to prolong it by ensuring that the consumer can interact with the product or brand in such a way that all the relevant senses of touch, olfactory, and sight are used to enhance the total product and the experience- an experience that turns the product into a brand, no matter when, where, or how the consumers interact with it (Joseph, 2010, p. 25).

Marketers will do well to remember a consumer's experience with any product. Apple included, that it is not something that begins only when they have the product in hand - it begins well before the consumer turns the product on. For example, in the case of the iPod, the experience begins when certain actions are depicted in the advertisements on TV or on billboards. Apple has aptly read its market when it placed a small sticker - "Designed in California, Made in China" - on their products, which communicated to their consumers the fact that Apple is concerned about costs but will not sacrifice ownership. Apple's success is based on the basic premise that by making the time one spends with an Apple product must be an enjoyable experience (Meyer \& Schwager, 2007, p. 119).

It is logical to accept the fact that previous experience with a product will shape future expectations the consumer may have of that product. Consumers will instinctively compare each new experience - positive or otherwise - with the experiences they have had in the past and judge it accordingly (Meyer \& Schwager, 2007, p. 120). Experience stagers from organisations are constantly refreshing their experiences offered to the consumers by 
changing or adding elements that keep their offering new, exciting, and worth paying money to experience all over again (Pine \& Gilmore, 1999, p. 95).

\section{Experiential Marketing Defined}

Experiential marketing is a process whereby the involvement of the consumer is mandatory in the form of participation and goes beyond meeting the consumer's identified wants and needs. It addresses not only the wants and needs, but the self-image, social goals, dormant emotions, values, and deeply ingrained desires of the consumer (Srinivasan \& Srivastava, 2010).

Brakus et al. (2009, p. 56) completed a qualitative study that explored the dimensions of experiential marketing and four dimensions emerged - sensory, affective, intellectual, and behavioural. The sensory dimension refers to the marketing efforts made to appeal to the fives human senses (i.e., the look and feel of an Apple product). Companies could also appeal to the consumer's intellect through creativity and innovativeness (i.e., the constant renewal of the Apple iOS operating system). The behavioural dimension aims to enrich consumers' lives by targeting their physical experiences by showing them alternative ways of doing things (i.e., highlighting the benefits of Apple products as compared to its competition). Through certain behaviour (i.e., the purchase of an iPhone), certain outcomes could manifest through the consumers' feelings or thoughts (i.e., the love of the iPhone after using it for a couple of days). The emotional connection between the consumer and the product is how the brand will be chosen over its competitors in future.

\section{Brand Loyalty and Advocacy}

As consumers fondly remember the memorable experiences and share them with peers and family, they could generate an increase in sales through the power of word-of-mouth and consumer loyalty (Srinivasan \& Srivastava, 2010). The timespan of loyalty is the basis for long-term profits for the organisation from a single consumer. Therefore, the rewards of brand loyalty could be long-term and cumulative (Griffin, 2002, p. 11). As the level of loyalty increases, consumers have the potential to become brand advocates (Pickton \& Masterson, 2010; Mutyala, 2010).

Brand advocates are consumers who “....select a single supplier from among all those they might consider, giving that supplier the highest share of spend possible and informally (without any form of compensation) telling others about how positive the relationship is and how much value and benefit they derive from it" (Lowenstein, 2011, p. 112). Share of spend, also known as share of wallet, is the percentage of overall business a consumer assigns to a service provider (Baumann, Elliot, \& Hamin, 2011, p. 250). In this case, it is the percentage of available income an Apple advocate is willing to spend on Apple products across different product categories.

These consumers are emotionally attached to the brand and possess a sense of ownership in it. Brand advocates are supportive and are loyal to the brand and would recommend and actively promote the brand via different channels (Rhoden, 2011, pp. 4-5). The concept of advocacy not only considers the likelihood of having an exclusive purchasing relationship, but also incorporates both strong brand-based, emotional kinship and active, positive and voluntary communication about, and on behalf of, the chosen supplier (Lowenstein, 2011, p. 9). There are Apple brand advocates who would stand in line for 28 hours to attend an opening of an Apple store (Kahney, 2003). The opening of the Apple store in Tokyo attracted over 8,000 people on opening day. With this as background, the methods applied by Apple were investigated and researched.

\section{RESEARCH METHODOLOGY}

For the purpose of this study, a mixed-method exploratory design was chosen. This method makes use of a qualitative and a quantitative approach by aiming to find out more regarding the constructs that need to be investigated. The researcher made use of the qualitative approach to identify themes and keywords that the Apple consumers use to relate to brand advocacy. This part of the research study was conducted through informal conversations on two Apple community blogs; namely, MacNN and MacRumors. 
The researcher utilised content analysis to analyse the data and identified themes for brand advocacy from the conversations. From the themes, the researcher created questions in preparation for the quantitative research method. The questions were incorporated into the quantitative study for the web-based questionnaire for measuring brand advocacy.

The quantitative research took the form of an online survey with close-ended questions and participants were asked to rate the statements according to their degree of agreement on a 5-point Likert scale ranging from "strongly agree" to "strongly disagree." This study made use of the brand experience scale and the brand loyalty scale used in the 2009 study by Brakus et al.

For this research study, snowball sampling was chosen which is a form of sampling that is used for reaching small, specialised populations (Aaker, Kumar, \& Day, 2009, p. 350), making it an appropriate method in this study. Research participants who volunteered to be in the study were asked to identify additional Apple consumers to participate.

The data were analysed using structural equation modelling (SEM) to determine how the measured variables (i.e., the four elements of experiential marketing) represent the constructs (i.e., experiential marketing, brand loyalty, and brand advocacy) and how the constructs are interrelated to one another.

\section{RESULTS}

Six themes emerged (see Table 1) from the qualitative research and they were converted into statement format to be used in the quantitative survey.

Table 1: Qualitative Themes and Statements

\begin{tabular}{|c|c|}
\hline Themes & Statements Drawn Up for Quantitative Survey \\
\hline Word-of-mouth recommendation & 1. I recommend Apple to my family and friends. \\
\hline A level of expectation met in respect to value and product & $\begin{array}{l}\text { 2. Apple meets and exceeds my expectations, in terms of } \\
\text { experience and value. }\end{array}$ \\
\hline A level of trust with the Apple brand & 3. I trust Apple and I am committed to its products. \\
\hline The functionality and design suits the needs of the consumers & 4. The functionality and design of Apple suits my needs. \\
\hline Consumers enjoy the sense of being in an Apple community & 5. I enjoy being a part of the Apple community. \\
\hline $\begin{array}{l}\text { Sense of superiority and irreplaceability compared to its } \\
\text { competitors }\end{array}$ & 6. I choose Apple as it is irreplaceable by other brands. \\
\hline
\end{tabular}

In the quantitative research section, 215 surveys were obtained and used for analysis. All respondents were asked a qualifying question of whether they use Apple products or not to determine their eligibility to participate in the research. The participants were further asked to rate their level of enthusiasm toward the Apple brand, in which $86.1 \%$ responded positively to the statement. The respondents were then asked to rate the 14 statements for experiential marketing, six for brand advocacy, and five for brand loyalty.

The reliability of the measured variables all fell between the reasonable range of $0.6-1$; therefore, the variables were verified as reliable. Behavioural brand experience had the closest reliability coefficient to 1 , which indicates that if another group of respondents were asked to rate the same statements, they were likely to provide similar results.

The factor loading, as illustrated in Figure 1, on all the items for all three constructs (i.e., experiential marketing, brand loyalty, and brand advocacy) were relatively high, which indicated good correlations among the measured variables. The Apple consumers who participated in the study seemed to have agreed with the items provided for each construct and found that they all measured what was set out in the study. 


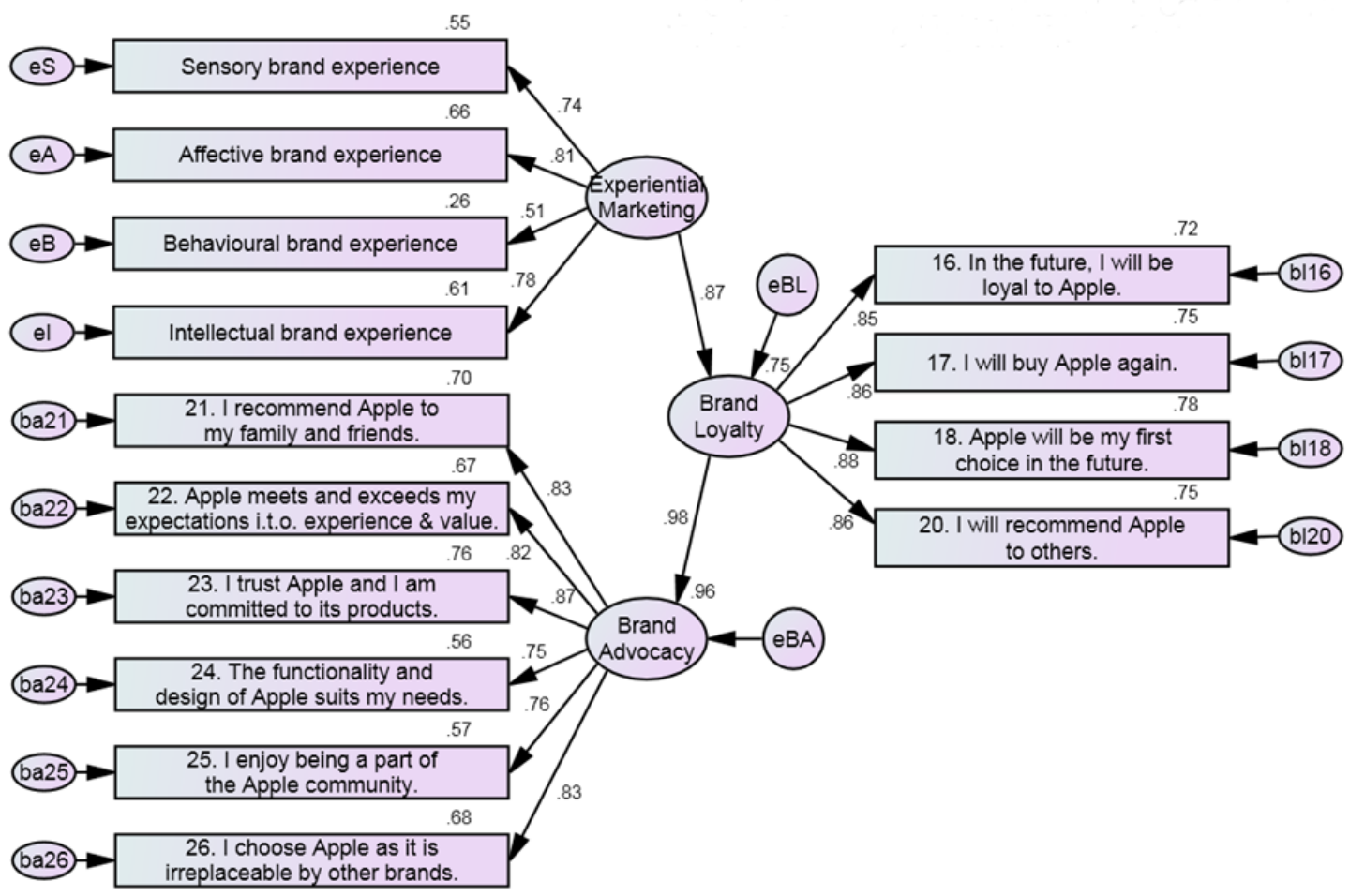

Figure 1: Structural Model

The primary objective of this study was to explore the effect of experiential marketing (EM) on brand advocacy (BA). The researcher also explored the possibility of a direct relationship between these two constructs. However, the direct effect was so small (0.0000) that it was virtually non-existent; therefore, it was not considered in this model. The total indirect effect (Zhao, Lynch, \& Chen, 2010) is the product of two regression coefficients. If the direct effect between the variables $\mathrm{A}$ and $\mathrm{B}$ is $a$ and the direct effect between variables $\mathrm{B}$ and $\mathrm{C}$ is $c$, the total indirect effect between variables $\mathrm{A}$ and $\mathrm{C}=a \mathrm{x} c$.

Therefore, the total indirect effect of EM on BA through brand loyalty (BL) was calculated as follows:

EM direct effect on BL $\mathrm{x}$ BL direct effect on $\mathrm{BA}=$ Total indirect effect

$0.87 \times 0.98=0.85$

The indirect effect of 0.85 between experiential marketing and brand advocacy suggests a strong relationship between these two factors through brand loyalty. Therefore, Apple consumers who are stimulated by the experiential marketing efforts of the company are very likely to become loyal to the brand and, in turn, there is a high likelihood of them becoming brand advocates.

\section{DISCUSSION AND CONCLUSION}

This study made use of the experiential marketing scale developed by Brakus et al. (2009) which consisted of thirteen questions divided into the four dimensions of experiential marketing; namely, sensory, intellectual, affective, and behavioural. Apple consumers indicated the highest level of agreement on the affective brand experience, which reveals a strong emotional attachment between the brand and the consumers. The majority of the 
participants indicated that Apple stimulates their thinking through intellectual experiences. The participants also considered Apple to be a brand with a high level of sensory experiences which indicates that Apple consumers could have stronger connections with the look and feel of the products than some of its competition.

The affective, sensory, and intellectual experiences attributed to the Apple products could be due to the personal nature of the products. Apple has introduced products like the iPod, iPhone, and iPad, which are small portable devices that could be highly personalised in their daily usage. Apple users could create their own playlists and name their devices as well as use them during work or leisure time. These are devices that have been well incorporated into the consumers' lifestyles. Like many other everyday items used by consumers today, the sensory elements of the Apple products have provided memorable experiences to its users.

The sense of excitement that precedes the introduction of new product launches often contributes toward the consumers' heightened sense of emotions. Apple users are known to stand in line for hours outside Apple stores in anticipation of new product launches. The hype and excitement that surrounds the launch of Apple products contribute heavily toward the affective brand experience.

This study confirmed the findings of Brakus et al. (2009) and the direct effect of experiential marketing on brand loyalty was represented by a regression weight of 0.87 . Thus, experiential marketing seems to have a strong influence of brand loyalty among Apple consumers. If an Apple consumer feels stimulated by the sensory and intellectual elements, feels emotionally attached to the brand, and feels motivated to action, these consumers are more likely to be loyal to Apple as a brand. These brand loyal consumers are more likely to buy an Apple product again and will choose Apple over other available brands.

There are many classifications of brand loyalty in secondary research. According to Mutyala (2010), consumers moved along the loyalty ladder through the phases of being a prospect, a consumer, a client, a supporter, and an advocate. This study further confirmed the effect of brand loyalty on brand advocacy. The direct effect of brand loyalty on brand advocacy was represented by a regression weight of 0.96 which signifies closeness between these two constructs being measured.

Therefore, Apple consumers who are loyal to the brand are found to exhibit strong tendencies toward becoming brand advocates. The consumers who continuously purchase Apple products over other brands are likely to recommend this brand to family and friends, as they perceive the superiority of the brand over its competitors. As loyalty develops, Apple consumers enjoy purchasing Apple products with others who share the same passion.

Brand experiences are very subjective and every company has their own way of interpreting their experiential marketing strategy. Experiential marketing is a holistic approach, which takes into account the consumers' experiences before, during, and after the actual purchases. From this study, it appears that the greater the brand experiences encountered by consumers, the higher the level of loyalty that is displayed by the consumers, who, in turn, are more likely to become brand advocates recruiting other brand advocates.

Apple chose to create a strong sensory stimulating and emotionally evoking brand and products, which, in turn, also motivates their consumers to act and think in a different way. As previously discussed, the company develops captivating and unique advertising campaigns to attract potential consumers. Apple also created a distinctive and personalised space in its Apple stores for consumers and prospects to purchase and experience the products. The company continued to innovate and develop its products to stimulate the consumers' curiosity and usage experiences. As these experiences become more meaningful to consumers, their level of loyalty increases and, in turn, they become brand advocates who have the potential to affect the revenues of Apple, one referral at a time.

This study centred on the perception of Apple consumers and the research methodologies used were based on the distinct characteristics of consumers who make use of Apple products. Therefore, the results cannot be generalised as it will not provide sufficient representativeness for use by other companies. A full research study should be conducted to determine a set of generic brand advocacy themes, which can be utilised by companies in different industries. 


\section{AUTHOR INFORMATION}

Mr. Ricardo Machado is a senior lecturer in the Department of Marketing and Retail Management at the University of South Arica. He has a wide academic and practical background from management positions in retailing and construction to a senior group marketing manager for a multinational food and beverage company. He has lectured extensively throughout South Africa at undergraduate, post-graduate, and executive development programmes. He graduated from the University of Tulsa (USA) with a BSc Cum Laude in Management Science, obtained an MBA in Finance, and subsequently obtained an Honours degree in Marketing from UNISA. E-mail: machar@unisa.ac.za

Prof. Michael C. Cant is the head of the Department of Marketing and Retail Management at the University of South Africa (UNISA). He has published over 50 accredited articles in refereed journals and is the editor and author of numerous marketing textbooks which are widely prescribed at universities in South Africa. He has presented papers at more than 45 conferences all over the world and is a well-respected marketing and retail scholar. He holds a DCom in Marketing from the University of South Africa. E-mail: cantmc@ unisa.ac.za (Corresponding author)

Helen Seaborne, Canada. E-mail: helenseaborne@gmail.com

\section{REFERENCES}

1. Aaker, D. A., Kumar, V., \& Day, G. S. (2009). Marketing research. USA, John Wiley.

2. Atwal, G., \& Williams, A. (2009). Luxury brand marketing - the experience is everything! Journal of Brand Management, 16(5/6), 338-346.

3. Baumann, C., Elliot, G., \& Hamin, H. (2011). Modelling customer loyalty in financial services - A hybrid of formative and reflective constructs. International Journal of Bank Marketing, 9(3), 247-267.

4. Brakus, J. J., Schmitt, B. H., \& Zarantonello, L. (2009). Brand experience: What is it? How is it measured? Does it affect loyalty? Journal of Marketing, 73, 52-68.

5. Chen, J., Ching, R. K. H., Luo, M. M., \& Liu, C. (2008). Virtual experiential marketing on online customer intentions and loyalty. Paper presented at the 41st Hawaii International Conference on System Sciences. Hawaii, 7-10 January, 2008.

6. Diller, S., Shedroff, N., \& Rhea, D. (2005). Making meaning: How successful businesses deliver meaningful customer experiences. USA: New Riders.

7. Fahy, J., \& Jobber, D. (2012). Foundations of marketing. USA: McGraw-Hill Education.

8. Gentile, C., Spiller, N., \& Noci, G. (2007). How to sustain the customer experience: an overview of experience components that co-create value with the customer. European Management Journal, 25(5), 395410.

9. Griffin, J. (2002). Customer loyalty: How to earn it, how to keep it. San Francisco: Jossey-Bass.

10. Grundey, D. (2008). Experiential marketing vs. traditional marketing: Creating rational and emotional liaisons with consumers. The Romanian Economic Journal, 29(3), 133-150.

11. Joseph, J. (2010). The experience effect: Engage Your customers with a consistent and memorable brand experience. USA: AMACOM Div American Mgmt Assn.

12. Kahney, L. (2003). Apple store: Chain of devotion. Wired.com. Retrieved 2011-03-11 from http://www.wired.com/print/gadgets/mac/news/2003/12/61513

13. Little \& King Integrated Marketing Group. (2008). Experiential marketing: Real interactions between brands and consumers through live experiences. In 41st Hawaii International Conference on System Sciences.

14. Lowenstein, M. W. (2011). The Customer advocate and the customer saboteur linking social word-ofmouth, brand impression, and stakeholder behavior. USA: ASQ Quality Press.

15. Meyer, C., \& Schwager, A. (2007). Understanding customer experience. Harvard Business Review, 1, 116126.

16. Mutyala, S. (2010). The loyalty ladder: A sideways look. Eight Leaves. Retrieved 2012-03-07 from http://www.eightleavesmedia.com/2010/04/the-loyalty-ladder-a-sideways-look/

17. Pickton, D., \& Masterson, R. (2010). Marketing: An introduction. United Kingdom: SAGE Publications. 
18. Pine, B. J., \& Gilmore, J. H. (1999). The experience economy: work is theatre \& every business a stage. USA: Harvard Business Press.

19. Rhoden, M. (2011). Cultivating customer advocates: more than satisfaction and loyalty. (Peppers \& Rogers Group white paper).

20. Schmitt, B. H. (2006). Why experiential marketing? Financial Times.

21. Schmitt, B. H. (2010). Customer experience management: A revolutionary approach to connecting with your customers. USA: John Wiley and Sons.

22. Srinivasan, S. R., \& Srivastava, R. K. (2010). Creating the futuristic retail experience through experiential marketing: is it possible? An exploratory study. Journal of Retail \& Leisure Property, 9(3), 193-199.

23. Zhao, X., Lynch, J., \& Chen, Q. (2010). Reconsidering Baron and Kenny: Myths and truths about mediation analysis. Journal of Consumer Research, 37(2), 197-206. 